\title{
Peningkatan Hasil Belajar Siswa Melalui Penerapan Model Pembelajaran Picture and Picture pada Mata Pelajaran IPS Materi Masyarakat Indonesia pada Masa Praaksara di Kelas VII SMPN 2 Lambitu Semester 1 Tahun Pelajaran 2020/2021
}

\author{
Fatimah \\ SMP Negeri 2 Lambitu, Bima, Indonesia \\ *Coresponding Author: f869768@gmail.com \\ Dikirim: 19-08-2021; Direvisi: 24-10-2021; Diterima: 25-10-2021
}

\begin{abstract}
Abstrak: Penelitian tindakan kelas ini bertujuan mendeskripsikan dan menganalisa penerapan dan dampak model pembelajaran picture and picture terhadap peningkatan hasil belajar pada mata pelajaran IPS materi masyarakat Indonesia pada Masa Praaksara kelas VII semester I SMPN 2 Lambitu. Subyek dalam penelitian ini adalah siswa kelas VII sebanyak 12 siswa terdiri dari 5 laki-laki dan 7 perempuan. Pada keadaan prasiklus, rata-rata nilai siswa 66 dan ketuntasan klasikal yang dicapai 73\%. Sementara kriteria keberhasilan yang ditetapkan adalah rata-rata nilai siswa $\geq 75$ dan ketuntasan kasikal $\geq 85 \%$. Setelah proses awal penelitian, pelaksanaan tindakan dengan memanfaatkan model pembelajaran picture and picture menunjukkan peningkatan pada hasil belajar siswa dan kinerja guru, dimana rata-rata nilai siswa mencapai 82.17 dan prosentase ketuntasan minimal pada 73.68. Peningkatan ini belum mencapai kriteria keberhasilan penelitian, sehingga diteruskan ke siklus II. Pada siklus II, peningkatan juga terjadi pada nilai rata-rata dan ketuntasan klasikal menjadi 87.11 dan $89.47 \%$. Demikian juga dengan kinerja guru, terjadi peningkatan signifikan dari siklus I dan siklus II. Perencanaan pembelajaran meningkat $2,33 \%$ dan pelaksanaan pembelajaran meningkat sebesar $1,86 \%$, mencapai indikator yang ditetapkan 90. Demikian juga pelaksanaan pembelajaran siklus II sebesar 97,10 mencapai indikator kinerja yang ditetapkan 90. Dengan perbaikan proses pembelajaran berhasil memenuhi indikator kinerja yang ditentukan. Peningkatkan hasil belajar siswa, disebabkan oleh peningkatan aktivitas pembelajaran siswa, interaksi guru dan siswa dalam proses pembelajaran di kelas dengan menggunkan penerapan model pembelajaran picture and picture yang dilaksanakan guru, sesuai dengan nilai kinerja guru. Dengan demikian setelah pelaksanaan perbaikan pembelajaran sampai siklus II, telah mencapai indikator kinerja yang ditetapkan, dan penelitian dianggap telah berhasil.
\end{abstract}

Kata Kunci: model pembelajaran Picture And Picture; pembelajaran IPS

Abstract: This classroom action research aimed to describe and analyze the application and impact of the picture and picture learning model on improving learning outcomes in social studies subjects for Indonesian society during the seventh semester of pre-character period at SMPN 2 Lambitu. The subjects in this study were class VII students as many as 12 students consisting of 5 boys and 7 girls. In the pre-cycle state, the average student score was 66 and the classical completeness achieved was $73 \%$. Meanwhile, the success criteria set were the average student score of 75 and $85 \%$ of classical completeness. After the initial research process, the implementation of the action using the picture and picture learning model showed an increase in student learning outcomes and teacher performance, where the average student score reached 82.17 and the minimum completeness percentage was 73.68. This increase has not reached the criteria for research success, so it was continued to cycle II. In the second cycle, an increase also occurred in the average value and classical completeness to 87.11 and $89.47 \%$. Likewise with teacher performance, there was a significant increase from cycle I and cycle II. Learning planning increased by $2.33 \%$ and 
learning implementation increased by $1.86 \%$, reaching the specified indicator of 90 . Likewise, the implementation of learning cycle II was 97.10, achieving the specified performance indicator of 90 . With the improvement of the learning process, it succeeded in meeting the specified performance indicators. . The increase in student learning outcomes was caused by an increase in student learning activities, teacher and student interactions in the learning process in the classroom by using the application of the picture and picture learning model carried out by the teacher, according to the teacher's performance value. Thus, after the implementation of learning improvement up to cycle II, the performance indicators have been achieved, and the research was considered successful.

Keywords: picture and picture learning model; social studies

\section{PENDAHULUAN}

Permendikbud Nomor 22 Tahun 2016 tentang Standar Proses menyebutkan proses pembelajaran pada satuan pendidikan diselenggarakan secara interaktif, inspiratif, menyenangkan, menantang, memotivasi pesertadidik untuk berpartisipasi aktif, serta memberikan ruang yang cukup bagi prakarsa, kreativitas, dan kemandirian sesuai dengan bakat, minat, dan perkembangan fisik serta psikologis peserta didik. Untuk itu setiap satuan pendidikan melakukan perencanaan pembelajaran, pelaksanaan proses pembelajaran serta penilaian proses pembelajaran untuk meningkatkan efisiensi dan efektivitas ketercapaian kompetensi lulusan.

Pada pembelajaran pra siklus, kelas VII SMPN 2 Lambitu pada mata pelajaran IPS materi masyarakat Indonesia pada masa praaksara, sebagaimana guru pada umumnya, peneliti merasa kesulitan memilih metode pembelajaran yang sesuai. Sehingga kembali pada metode andalan yang sebenarnya termasuk metode konensional yakni metode ceramah berbasis buku teks, tanpa persiapan media pembelajaran yang memadai. Karena materi pembelajaran masyarakat Indonesia pada masa praaksara relatif asing bagi siswa, dimana siswa belajar jauh pada masa lampau yang kondisinya berbeda dengan saat ini. Hal ini teryata menjadi salah satu kendala dalam pencapaian keberhasilan proses pembelajaran, karena tidak sesuai dengan karakteristik Kurikulum 2013.

Pada pembelajaran pra-siklus sebagaimana peneliti paparkan di awal mengalami kesulitan mewujudkan proses pembelajaran secara interaktif, inspiratif, menyenangkan, menantang, memotivasi pesertadidik untuk berpartisipasi aktif, serta memberikan ruang yang cukup bagi prakarsa, kreativitas, dan kemandirian sesuai dengan bakat, minat, dan perkembangan fisik serta psikologis peserta didik. Selama proses pembelajaran partisipasi siswa rendah, karena memang materinya asing dan yang dijelaskan berupa peninggalan-peninggalan nyaris tidak dapat dilihat para siswa saat ini, peneliti cenderung mendominasi proses pembelajaran. Prakarsa dan kreativitas siswa juga rendah dimana siswa menunggu perintah dari peneliti sebagai guru, demikian juga siswa belum mampu menunjukkan kemadiriannya.

Hasil dari proses pembelajaran pra-sikluspun mata pelajaran IPS kelas VII pada materi masyarakat Indonesia pada masa praaksara rendah. Dengan menggunakan instrumen APKG, nilai kinerja guru belum memuaskan yakni : adapun target nilai kinerja guru adalah 90 untuk prencanaan pembelajaran dan 90 untuk pelaksanaan pembelajaran. Dari aspek siswa, prosentase ketuntasan secara klasikal mencapai $73 \%$, dengan rata-rata nilai siswa 66. Sudah barang tentu ini jauh dari

@2021 JPPI (https://jurnal.bimaberilmu.com/index.php/jppi) 
harapan penelti. Target yang peneliti canangkan untuk keberhasilan proses pembelajaran adalah ketuntasan klasikal $85 \%$ dengan nilai rata-rata minimal 75 .

Hasil proses pembelajaran pra-perbaikan tersebut dapat diintentifikasi permasalahan pembelajaran yang telah dilaksanakan sebagai berikut: 1) siswa pasif selama proses pembelajaran, 2) metode, model pembelajaran yang kurang tepat untuk kondisi siswa dan karakterisitik materi pembelajaran, 3) tidak adanya media pembelajaran yang dibutuhkan dan diinginkan siswa, dan 4) hasil belajar siswa rendah. Karena permasalahannya materi terlalu asing bagi siswa dan relatif langkanya peninggalan masa praaksara yang dapat dilihat oleh siswa, tidak tepatnya metode, model pembelajaran dan tidak adanya media pembelajaran menjadi pokok pemikiran dan kajian.

Salah satu yang menarik perhatian anak-anak adalah gambar. Dengan gambargambar yang dikaitkan pembelajaran IPS kelas VII khususnya pada materi masyarakat Indonesia pada masa praaksara, diharapkan pembelajaran akan lebih menarik, menyenangkan, karena siswa dengan dapat memiliki gambaran tentang materi tersebut secara visual. Langkah tersebut dapat merangsang siswa aktif sekaligus meningkatkan prestasi belajarnya.

Model pembelajaran yang tepat dengan kondisi siswa dan karakteristik materi pembelajaran tersebut adalah model pembelajaran picture and picture. Dengan model pembelajaran tersebut diharapkan permasalahan pembelajaran akan dapat teratasi, sekaligus meningkatkan hasil belajar siswa.

\section{KAJIAN TEORI}

\section{Pembelajaran Ilmu Pengetahuan Sosial (IPS)}

Ilmu Pengetahuan Sosial (IPS) merupakan mata pelajaran yang mengkaji tentang isu-isu sosial dengan unsur kajiannya dalam konteks peristiwa, fakta, konsep, dan generalisasi. Tema yang dikaji dalam IPS adalah fenomena-fenomena yang terjadi di masyarakat baik masa lalu, masa sekarang, dan kecenderungannya di masamasa mendatang.

Tujuan utama dari pembelajaran IPS ini adalah untuk membina para peserta didik menjadi warganegara yang mampu mengambil keputusan secara demokratis dan rasional yang dapat diterima oleh semua golongan yang ada di dalam masyarakat, memiliki kemampuan berkomunikasi, bekerjasama, dan berkompetisi dalam masyarakat yang majemuk, di tingkat lokal, nasional, dan global.

Ruang lingkup mata pelajaran IPS meliputi aspek-aspek sebagai berikut: 1) keruangan dan konektivitas antar ruang dan waktu, 2) perubahan masyarakat Indonesia pada zaman praaksara, zaman Hindu-Buddha dan zaman Islam, zaman penjajahan dan tumbuhnya semangat kebangsaan, masa pergerakan kemerdekaan sampai dengan awal reformasi, 3) jenis dan fungsi kelembagaan sosial, budaya, ekonomi dan politik dalam masyarakat, dan 4) interaksi manusia dengan lingkungan alam, sosial, budaya, dan ekonomi;

Dalam pelaksanaannya, pembelajaran IPS telah mengalami perubahan pada proses pembelajaran sebagaimana yang diamanatkan oleh Kurikulum 2013. Adapun perubahan tersebut terdapat pula karakteristik lain dalam pembelajaran IPS dalam kurikulum 2013 ialah pembelajaran secara terpadu serta pembelajaran IPS dengan pendekatan saintifiknya. 
Pelaksanaan pembelajaran IPS dengan pendekatan saintifik dapat dikatan belum dapat berjalan secara baik. Olehnya itu, berdasarkan kutipan konsepsi wawancara tersebut diatas dari berbagai penjelasan serta pengakuan informan dalam rangka pelaksanaan pendekatan saintifik dalam pembelajaran dimana dalam pelaksanaan tersebut belum sepenuhnya menunjukan langkah-langkah saintifik serta adapun langkah-langkah siantifik yang masih terlewatkan.

Dengan kebanyakan langkah-langkah yang terdapat dalam pendekatan saintifik berdampak juga pada kesulitan guru dalam mengaktualisasikannya dalam bentuk satuan pembelajaran. Sangat terlihat bahwa guru dalam memberikan pembelajaran masih tetap sama pada pembelajaran kurikulum sebelumnya sehingga kurang mengarahkan pembelajaran pada pendekatan saintifiknya. Dengan adanya kesulitan yang dialami oleh guru dalam melaksanakan pembelajaran IPS dengan pendekatan saintifik karena kurang kesiapan guru maupun sekolah serta pemerintah yang juga turut serta dalam kesiapan pendidik guna melaksanakan program pemerintah tersebut.

Terlepas itu pula, kreaktivitas guru juga sangat penting. Karena guru yang tidak kretiv juga sangat mempengaruhi serta berdampak pada pelaksanaan pembelajaran IPS dengan pendekatan saintifik. Dengan demikian, kreaktivitas juga menjadi penentu bagi guru dalam memilih serta mampu menentukan dan mengarahkan kegiatan pembelajaran tersebut.

Selain itu, kreaktivitas guru juga di tuntut guna dapat menentukan metode pembelajaran ataupun scenario dalam pembelajaran sehingga guru mampu menciptakan pelaksanaan pembelajaran IPS dengan pendekatan sainifikn serta langkah-langkahya yang diketahui bermula pada mengamati, menalar, menanya, mencoba, dan mengkomunikasikan.

Walaupun pendekatan saintifik dalam pembelajaran IPS belum dapat berjalan secara maksimal yang dilaksanakan oleh guru, namun kegiatan pembelajaran sudah membawa pada arah untuk siswa aktif dan guru hanya sebagai fasilitator saat berlangsungnya pelaksanaan pembelajaran. Hal tersebut dikarenakan dalam penggunaan diskusi yang dilaksanakan dengan model cooperative learning dan problem based learning yang digunakan oleh guru pada setiap pembelajaran guna mendukung pembelajaran student center. Selanjutnya dalam mengaplikasikan pembelajaran IPS dengan pendekatan saintifiknya gurupun telah mampu menunjukannya dengan pembelajaran yang kontekstual dengan mengarahkan pembelajaran tersebut dalam fenomena alam serta fenomena sosial dalam berlangsungnya kegiatan pembelajaran dalam kelas.

Pelaksanaan pembelajaran terpadu dalam mata pelajaran IPS merupakan suatu program pembelajaran melalui pendekatan multidisiplin dan pendekatan terpadu sebagai disiplin ilmu-ilmu sosial. Ilmu-ilmu sosial yang terlibat dalam IPS adalah geografi, ekonomi, sejarah, sosiolgi, politik, psikologi, dan antropologi. Selanjutnya materi ajar yang diambil dari berbagai ilmu-ilmu sosial yang menyangkut dengan masalah konsep, generalisasi dan teori.

Dengan demikian, pembelajaran terpadu IPS dalam mata pelajaran IPS merupakan suatu kosep pembelajaran yang dituntut untuk mampu menyampaikan materi-materi dari disiplin ilmu sosial secara terpadu, yaitu sejarah, geografi, ekonomi dan sosiologi. Terlepas itu pula, pembelajaran IPS dalam kurikulum 2013, telah dikembangkan sebagai mata pelajaran integrative social studies dan 
hal tersebut didukung dari kompetensi yang telah disusun secara terpadu yang terdapat pada tema tertentu.

\section{Model Pembelajaran Picture and Picture}

Picture and picture menurut Shoimin (2014) dalah suatu model pembelajaran kooperatif dengan menggunakan media gambar. Dalam operasionalnya gambar- gambar dipasangkan satu sama lain atau bisa jadi di urutkan menjadi urutan yang logis. Metode pembelajaran ini mengandalkan gambar yang menjadi faktor utama dalam proses pembelajaran. Maka dari itu, sebelumnya guru sudah menyiapkan gambar yang akan ditampilkan, baik dalam bentuk kartu atau chart dalam ukuran besar.

Picture and picture berbeda dengan media gambar dimana picture and picture berupa gambar yang belum disusun secara berurutan dan yang menggunakan adalah peserta didik, sedangkan media gambar berupa gambar utuh yang digunakan oleh guru dalam proses pembelajaran. Dengan adanya penyusunan gambar guru dapat mengetahui kemampuan peserta didik dalam memahami konsep materi dan melatih berfikir logis dan sistematis.

Menurut Suprijono (2009), model pembelajaran picture and picture adalah metode pembelajaran yang menggunakan gambar dipasangkan atau diurutkan menjadi urutan logis. Dalam hal ini guru menyampaikan kompetensi yang ingin dicapai, menyampaikan materi sebagai pengantar. Setelah itu guru menunjukkan atau memperlihatkan gambar-gambar yang berkaitan dengan materi. Siswa tidak hanya mendengar dan membuat catatan, guru memanggil siswa secara bergantian memasang atau mengurutkan gambar-gambar menjadi urutan yang logis. Setelah potongan-potongan gambar menjadi urutan yang runtut, siswa ditanya alasan atau dasar pemikiran urutan gambar tersebut.

Inovatif artinya setiap pembelajaran harus memberikan sesuatu yang baru, berbeda dan selalu menarik minat peserta didik. Sementara kreatif artinya setiap pembelajaran harus menimbulkan minat kepada peserta didik untuk menghasilkan sesuatu atau dapat menyelesaikan suatu masalah dengan menggunakan metode, teknik, atau cara yang dikuasai oleh mereka yang diperoleh dari proses pembelajaran. a. Langkah-langkah model pembelajaran picture and picture

Langkah-langkah dalam metode Picture and picture menurut Hamdani (2011) adalah sebagai berikut: 1) penyampaian kompetensi yang ingin dicapai, 2) penyajian materi sebagai pengantar, 3) menunjukkan atau memperlihatkan gambar-gambar yang berkaitan dengan materi secara interaktif dan menyenangkan, 4) mengurutkan gambar sesuai urutan logis oleh siswa secara bergantian, 5) tanya jawab terkait pemahaman siswa terhadap urutan gambar tersebut, 6) dari alasan atau urutan gambar tersebut, konsep atau materi ditanamkan pada siswa, dan 7) bersama-sama menyusun kesimpulan dan rangkuman.

Berdasarkan uraian diatas dapat disimpulkan bahwa model pembelajaran picture and picture pada dasarnya merupakan salah satu strategi pembelajaran yang dapat menjawab persoalan bagaimana belajar itu bermakna, menyenangkan, kreatif, dan sesuai dengan realita yang ada serta lebih melibatkan peserta didik aktif belajar, baik secara mental, intelektual, fisikal, maupun sosial.

b. Kelebihan model pembelajaran picture and picture

Adapun kelebihan model pembelajaran picture and picture menurut Istarani (2011) adalah: 1) materi yang diajarkan lebih terarah karena pada awal pembelajaran 
guru menjelaskan kompetensi yang harus dicapai dan materi secara singkat terlebih dahulu, 2) peserta didik lebih cepat menangkap materi ajar karena guru menunjukkan gambar-gambar mengenai materi yang dipelajari, 3) dapat meningkatakan daya nalar atau daya pikir peserta didik, 4) dapat meningkatkan tanggung jawab peserta didik, dan 5) pembelajaran lebih berkesan, sebab peserta didik dapat mengamati langsung gambar yang telah dipersiapkan oleh guru.

c. Kekurangan Model pembelajaran picture and picture

Adapun kekurangan model pembelajaran picture and picture adalah: 1) sulit menemukan gambar-gambar yang bagus dan berkualitas serta sesuai dengan materi pelajaran, 2) sulit menemukan gambar-gambar yang sesuai dengan daya nalar atau kompetensi peserta didik yang dimiliki, dan 3) baik guru ataupun peserta didik kurang terbiasa dalam menggunakan gambar sebagai bahan utama dalam membahas suata materi pelajaran.

\section{METODE PENELITIAN}

Perbaikan pembelajaran didesain dalam bentuk penelitian tindakan kelas. Penelitian jenis dilakukan dalam rangka memberikan kajian yang bersifat reflektif oleh pelaku tindakan (guru) untuk meningkatkan kemampuan rasional dari tindakantindakan yang dilakukan dan untuk memperbaiki kondisi dimana praktik pembelajaran tersebut dilakukan (Raka Joni, 1980: 22). Melalui PTK guru menginginkan terjadinya perubahan, peningkatan, dan perubahan pembelajaran yang lebih baik, sehingga tujuan pembelajaran dapat tercapai secara optimal.

Penelitian pada mata pelajaran IPS pada materi masyarakat Indonesia pada masa praaksara melibatkan sebanyak 12 siswa terdiri dari 5 laki-laki dan 7 perempuan di kelas VII SMPN 2 Lambitu. Adapun rata-rata intake siswa adalah cukup, fasilitas sekolah untuk proses pembelajaran baik.

Data yang diambil berupa: 1) hasil belajar, diteliti sejauh mana hasil belajar siswa kelas VII SMPN 2 Lambitu khususnya pada mata pelajaran IPS, dan 2) kinerja guru, diteliti sejauh mana ketuntasan guru dalam melaksanakan dan menyelesaikan rencana pelaksanaan pembelajaran. Instrumen yang digunakan dalam penelitian berupa post test dan lembar observasi kinerja guru.

Untuk mengetahui keberhasilan penelitian, data disandingkan dengan kriteria keberhasilan yang ditetapkan sebelumnya, yaitu: 1) hasil belajar siswa dengan ratarata nilai post test mencapai $\geq 75,2$ ) prosentase ketuntasan belajar siswa $\geq 85 \%$, dan 3) kinerja guru, dimana ketuntasan guru dalam menyelesaikan perencanaan dengan baik mencapai $\geq 90.00$, dan dalam pelaksanaan pembelajaran dengan baik mencapai $\geq 90.00$.

\section{HASIL DAN PEMBAHASAN}

\section{Pra-siklus}

Sebelum melaksanakan perbaikan pembelajaran dalam siklus, guru melaksanakan pembelajaran pra-perbaikan, tujuannya untuk mengetahui kemampuan awal siswa dalam pemahaman tentang materi kebebasan berorganisasi. Tes ini berguna untuk menentukan tindakan yang cocok dengan kondisi siswa. Pembelajaran Pra-perbaikan dilakukan terlebih dahulu, materi kebebasan berorganisasi tanpa menggunakan model pembelajaran picture and picture. Rata-rata nilai siswa dan 
ketuntasan belajar adalah 66 dan $73 \%$. Keadaan pra-siklus ini dapat menjadi dasar untuk melihat perubahan yang terjadi setelah diberikan tindakan selain pencapaian kriteria keberhasilan yang ditetapkan sebelumnya.

\section{Siklus I}

Penyusunan RPP sebagai bagian dari proses perencanaan penelitian, dimulai dengan mempersiapkan gambar dengan jumlah yang cukup untuk menjelaskan materi masyarakat Indonesia pada masa praaksara. Gambar-gambar diurutkan sesuai masa, dan disiapkan deskripsi yang jelas dan lengkap tentang gambar tersebut. Langkah-langkah disusun dalam pembelajaran yang runtut sehingga mencerminkan model pembelajaran picture and picture. Selain penyusunan RPP, peneliti beserta rekan sejawat juga menyusun instrumen-instrumen penelitian yang diperlukan.

Setelah proses perencanaan dilakukan, guru menerapkan model pembelajaran picture and picture sesuai dengan rencana. Adapun hasil perbaikan pembelajaran Siklus I disajikan dalam Tabel 1.

Tabel 1. Hasil perbaikan pembelajaran IPS Siklus 1

\begin{tabular}{ccc}
\hline & Pra-siklus & Siklus I \\
\hline Rata-rata Nilai & 66 & 82.17 \\
\hline \% Ketuntasan Klasikal & 73 & 73.68 \\
\hline
\end{tabular}

Hasil perbaikan pada siklus I menunjukkan peningkatan pada rata-rata nilai post test siswa, walaupun prosentase ketuntasan belajar klasikal belum menunjukkan peningkatan yang berarti.

Sementara itu, kinerja guru dapat diamati dalam Tabel 2 untuk siklus I. Nilai kinerja guru menunjukkan bahwa kinerja guru dalam perencanaan maupun pelaksanaan pembelajaran belum mencapai kriteria yang diinginkan.

Tabel 2. Kinerja Guru Siklus 1

\begin{tabular}{cc}
\hline & Siklus I \\
\hline Perencanaan Pembelajaran & 87.17 \\
\hline Pelaksanaan Pembelajaran & 82.24 \\
\hline
\end{tabular}

Pada pembelajaran siklus I, siswa tertarik mengikuti proses pembelajaran karena bermain dengan gambar-gambar berkaitan materi masa Praaksara. Motivasi belajar siswa meningkat karena persoalan yang disampaikan oleh guru berkaitan dengan permasalahan gambar yang belum pernah dilihat sisiwa. Siswa belajar tanpa merasa bahwa dia sedang belajar materi tersebut. Guru menunjukkan/ memperlihatkan gambar-gambar yang berkaitan dengan materi masa Praaksara.

Dalam proses penyajian materi, guru mengajak siswa ikut terlibat aktif dalam proses pembelajaran dengan mengamati setiap gambar yang ditunjukan oleh guru dengan deskripsi yang disiapkan dengan bahasa yang ringkas dan jelas. Dengan gambar menghemat energi guru dan siswa lebih mudah memahami materi yang diajarkan. Dalam perkembangan selanjutnya sebagai peneliti melakukan memodifikasikan gambar berselang seling dengan presentasi power point serta melengkapi gambar dengan video terkini yang berkaitan dengan gambar tersebut.

Pada langkah guru menunjuk/memanggil siswa secara bergantian untuk memasang/mengurutkan gambar-gambarmateri masa Praaksara menjadi urutan yang logis, siswa sangat senang dan mereka berusaha menyelesaikannya secepat mungkin. 
Dalam kelompok siswa berusaha menyelesaikan secepatnya dengan urutan yang tepat serta alasan yang logis.

Pada langkah guru menanyakan alasan/dasar pemikiran dari urutan gambar tersebut dimana siswa dilatih untuk mengemukan alasan pemikiran atau pendapat tentang urutan gambar tersebut, siswa mengalami kendala dimana sebagian siswa tidak mampu secara aktif mengemukakan pendapatnya. Meskipun terhambat proses ini dapat dilalui, dilanjutkan dengan guru menjelaskan langkah berikutnya.

Pada langkah mendiskusikan kesimpulan materi yang baru saja diterimanya berbasis gambar yang telah diurutkan secara logis materi masyarakat Indonesia pada masa praaksara mengalami hambatan, dimana belum seluruh siswa aktif melakukannya. Meskipun pembelajaran telah berjalan dengan baik namun pada keseluruhan langkah belum optimal.

Mengamati hasil belajar siswa, ketuntasan klasikal dan kinerja guru yang belum mencapai kriteria keberhasilan yang ditetapkan sebelumnya, maka peneliti melanjutkan ke siklus II dengan melakukan refklesi pada kekurangan-kekurangan siklus I pada beberapa bagian, yaitu: 1) pada perencanaan guru perlu melengkapi gambar-gambar sesuai dengan materi yang disajikan, sehingga lebih menarik bagi siswa, 2) pada langkah menyimpulkan isi materi pembelajaran, peranan siswa belum optimal, hal ini disebabkan guru belum efektif dalam mengekploitasi kemampuan dan keberanian siswa untuk mengemukakan pendapat berrdasarkan gambar yang telah disusun secara logis, 3) fungsi gambar dalam pembelajaran siklus I belum optimal, sehingga pada langkah-langkah akhir kegiatan inti fungsi gambar berkurang, padahal yang seharusnya bertambah.

\section{Siklus II}

Dengan merujuk pada hasil refleksi siklus I, maka perencanaan RPP dan instrument siklus II dimanfaatkan untuk memodifikasi dan meningkatkan langkahlangkah pembelajaran yang belum optimal pada siklus I. RPP hasil modifikasi ini kemudian diaplikasikan dalam kelas yang menjadi subjek penelitian. Adapun hasil perbaikan pembelajaran siklus II disajikan dalam Tabel 3 untuk rata-rata nilai siswa dan ketuntasan klasikal yang dicapai.

Tabel 3. Hasil perbaikan pembelajaran IPS Siklus 2

\begin{tabular}{cccc}
\hline & Pra-siklus & Siklus I & Siklus II \\
\hline Rata-rata Nilai & 66 & 82.17 & 87.11 \\
\hline Ketuntasan Klasikal & 73 & 73.68 & 89.47 \\
\hline
\end{tabular}

Dari tabel diatas dapat dilihat bahwa telah terjadi peningkatan dibanding sebelum perbaikan pembelajaran. Demikian pula rata-rata hasil belajar siswa siklus II meningkat dibanding siklus I, yakni terjadi peningkatan rata-rata nilai siswa sebesar 12,13 dan ketuntasan belajar klasikan sebesar 5.47\%.

Peningkatan pada siklus II diperoleh dari upaya perbaikan pelaksanaan pembelajaran dengan langkah: 1) menyimpulkan isi materi pembelajaran, peranan siswa lebih optimal, hal ini disebabkan guru lebih efektif dalam mengekploitasi kemampuan dan keberanian siswa untuk mengemukakan pendapat berrdasarkan gambar yang telah disusun secara logis, dan 2) penggunaan fungsi gambar dalam pembelajaran siklus II telah optimal, sehingga pada langkah-langkah akhir kegiatan inti fungsi gambar bertambah. 
Pada kinerja guru, peningkatan yang signifikan juga terjadi, seperti nilai yang ditunjukkan dalam Tabel 4.

Tabel 4. Kinerja Guru Siklus 2

\begin{tabular}{ccc}
\hline & Siklus I & Siklus II \\
\hline Perencanaan Pembelajaran & 87.17 & 93.50 \\
\hline Pelaksanaan Pembelajaran & 82.24 & 97.10 \\
\hline
\end{tabular}

Kinerja guru demikian juga mengalami peningkatan signifikan dari siklus I dan siklus II. Perencanaan pembelajaran meningkat 2,33\% dan pelaksanaan pembelajaran meningkat sebesar $1,86 \%$.

Dengan demikian, penerapan model pembelajaran picture and picture berhasil meningkatkan hasil belajar siswa pada mata pelajaran IPS materi masyarakat Indonesia pada masa praaksara kelas VII semester I SMPN 2 Lambitu. Secara umum proses pembelajaran dengan penerapan model pembelajaran picture and picture berjalan dengan baik. Sebagaimana dikemukakan Shoimin (2014) dalah suatu model pembelajaran kooperatif dengan menggunakan media gambar. Dalam operasionalnya gambar-gambar dipasangkan satu sama lain atau bisa jadi di urutkan menjadi urutan yang logis. Metode pembelajaran ini mengandalkan gambar yang menjadi faktor utama dalam proses pembelajaran. Fungsi gambar pada siklus II lebih optimal dalam menunjang ketercapaian tujuan pembelajaran.

Keberhasilan penelitian ditandai dengan: 1) hasil belajar siswa siklus II ratarata 87,00 melewati indikator kinerja yakni $\geq 75$; ketuntasan belajar klasikal siklus II $87,07 \%$ melewati indikator kinerja $\geq 85 \%$, 2) kinerja guru siklus II, perencanaan pembelajaran 91,50, mencapai indikator yang ditetapkan 90, dan juga pelaksanaan pembelajaran siklus II sebesar 91,10 melewati indikator kinerja yang ditetapkan 90 . Dengan tercapainya indikator kinerja tersebut maka penelitian tidak dilanjutkan lagi ke siklus berikutnya.

\section{KESIMPULAN DAN SARAN}

Dalam penelitian ini, kesimpulan yang dicapai adalah bahwa penerapan model pembelajaran picture and picture dapat meningkatkan hasil belajar siswa dan kinerja guru dalam perencanaan dan pelaksanaan pembelajaran pada mata pelajaran IPS materi masyarakat Indonesia pada masa praaksara kelas VII semester I SMPN 2 Lambitu tahun pelajaran 2020/2021.

Adapun yang perlu diperhatikan oleh guru mata pelajaran IPS maupun peneliti selanjutnya adalah: 1) variasi dan ketersediaan gambar yang menarik bagi siswa, 2) penyampaian gambar yang interaktif dan menggunakan alternatif ice breaking yang variatif, serta 3) penggunaan waktu yang maksimal sangat diperlukan dalam penerapan model pembelajaran picture and picture ini.

\section{DAFTAR PUSTAKA}

Shoimin, Aris. (2014). Model Pembelajaran Inovatif Dalam Kurikulum 2013. Yogyakarta: Ar Ruzz Media. 
Suprijono, Agus. (2009) Cooperative Learning Teori dan Aplikasi PAIKEM. Jakarta: Rineka Cipta.

Dirjen Dikdasmen. (2005). Kurikulum 2004 Pedoman Pengembangan Silabus dan Model Pembelajaran Mata Pelajaran IPS. Jakarta: Dirjen Dikdasmen.

Dirjen Dikdasmen. (2005). Kurikulum 2004 Pedoman Pengembangan Silabus dan Pembelajaran IPS. Jakarta: Dirjen Dikdasmen.

Hamdani. 2011. Strategi Belajar Mengajar. Bandung: Pustaka Setia.

Istarani. 2011. Model Pembelajaran Inovatif (Referensi Guru dalam Menentukan Model Pembelajaran). Medan : Media Persada.

Nurhadi (2002). Contextual Teaching and Learning (picture and picture). Jakarta: Dirjen Dikdasmen.

Raka Joni, T. (1980). Strategi belajar mengajar : suatu tinjauan pengantar/ T.Raka Joni. Jakarta : Departeman Pendidikan dan Kebudayaan. 